\title{
ETIKA BELAJAR DAN MENGAJAR
}

\author{
Zailani \\ Dosen Fakultas Agama Islam Universitas Muhammadiyah Sumatera Utara \\ (Email:jai_ananda45@yahoo.co.id)
}

\begin{abstract}
Abstrak
Judul tulisan ini adalah Etika Belajar dan Mengajar. Dalam Aktivitas Belajar mengajar, etika apa sajakan yang diperlukan antara kedua belah pihak, agar terjalin hubungan yang hormanis antara si guru dan si murid. Tulisan ini bertujuan agar ada rasa saling mengetahui dan memahami etika masing-masing. Agar terjadi komunikasi hangat dan saling menghargai di antara kedua belah pihak. Landasan yang digunakan dalam menjabarkan etika belajar mengajar menitik-tekankan kepada etika Islam, sehingga sumber rujukan yang digunakan adalah Al-quran dan Sunnah serta pendapat para ulama yang berkonsentrasi dalam pendidikan Islam, yang pada titik simpulnya bahwa etika, atau yang lebih familiar akhlak dalam Islam merupakan metode paling ampuh dalam transferknowladge pada siswa. Juga sesuatu yang sangat penting dalam tradisi pendidikan. Karena orientasi dari pendidikan Islam adalah memanusiakan manusia.
\end{abstract}

Keywords: Etika, belajar dan mengajar

\section{A. Pendahuluan}

Kesempurnaan

manusia

bukan hanya terletak pada wujudnya.

Tetapi juga potensi yang dimiliki, yakni proses belajar yang tidak dimiliki oleh makhluk lain. Dengan kesempatan yang cukup besar untuk mempelajari segala macam ilmu pengetahuan, menjadikan manusia sebagai makhluk yang unik. Dengan segala indra dan daya akal yang luar biasa. Mampu mengingat berbagai ilmu pengetahuan yang sangat kompleks. membuat insan menjadi tertinggi dalam kehidupan untuk mengatur kehidupan.

Belajar menjadi bagian yang diperintahkan Allah. Proses tersebut diawali semenjak dilahirkan sampai ajal menjemput. Dalam Islam untuk mendapat kemuliaan belajar, etika harus dilibatkan ketika proses intraksi antara yang belajar dan mengajar berlangsung. Dalam konteks belajar dan mengajar dalam perspektif Islam, etika yang dimaksud di sini adalah akhlak, bersumber dari Alquran dan 
Sunnah. Ini menjadi hal menarik untuk dikaji. Karena etika belajar dalam Islam mengikuti rambu-rambu agama. Hal-hal apa saja yang mesti dianjurkan ataupun yang dilarang dalam dalam kondisi belajar? Bagaimana bersikap kepada guru dan materi yang dipelajari? Ini Merupakan bagian tidak bisa lepas dari etika belajar. Apalagi tujuan belajar dan mendapatkan ilmu, di dalamnya terkandung alasan teologis, yakni mengagungkan Allah.

Mengajar adalah sikap yang terpuji. Dalam perspektif Islam, seorang yang mengajar harus mengikutkan nilai, secara langsung terintegrasi dalam proses mengajar. Sama dengan etika belajar di atas. Keteladanan mengajar menjadi bagian yang tidak terpisahkan. Etika apa saja yang menjadi nilai fundamental yang harus dimiliki seorang pengajar hal yang menarik untuk dibahas.

\section{B. Pengertian Etika, Belajar dan Mengajar}

\section{a. Etika}

Kata etika adalah adalah ilmu tentang apa yang baik dan yang buruk, tentang hak dan kewajiban moral. Kumpulan asas/nilai yang berkenaan dengan akhlak, nilai mengenai yang benar dan salah yang dianut masyarakat. ${ }^{1} \quad$ Jika diteliti dengan baik, etika tidak hanya sekadar sebuah ilmu tentang yang baik dan buruk ataupun bukan hanya sekadar sebuah nilai, tetapi lebih dari itu bahwa etika adalah sebuah kebiasaan yang baik dan sebuah kesepakatan yang diambil berdasarkan suatu yang baik dan benar. ${ }^{2}$ Dari asal usul kata, "Etika berasal dari bahasa Yunani "ethos" yang berarti adat istiadat/kebiasaan yang baik. Perkembangan etika studi tentang kebiasaan manusia berdasarkan kesepakatan, menurut ruang dan waktu yang berbeda, yang menggambarkan perangai manusia dalam kehidupan pada umumnya. ${ }^{3}$ Menurut $\mathrm{K}$ Bertens etika juga bisa bermakna Kebiasaan, adat, watak, akhlak, sikap dan cara berpikir.

\footnotetext{
1 Tim Penyusun Departemen Pendidikan Nasional, Kamus Besar Bahasa Indonesia (Jakarta: Gramedia Pustaka,2007) h.309.

${ }^{2}$ Maidiantus, "Pendidikan Kajian Etis tentang Krisis Moral Berdampak Pada pendidikan," dalam Jaffray, vol.2, Oktober 2014, h. 237.

3 Ibid. lihat juga Surajiyo, Ilmu Filsafat Suatu Pengantar (Jakarta: Bumi Aksara, 2005), h. 88.
} 
Dalam bentuk jamak (ta etha) artinya: adalah adat Kebiasaan dan arti terakhir inilah yang menjadi latar belakang bagi terbentuknya istilah etika, ${ }^{4}$ begitu juga dengan moral. $^{5}$

Secara subtansi, pengertian di atas menunjukkan kesamaan sikap dan kebiasaan. Namun Pemakalah menganalisis bahwa suatu kebiasaan

${ }^{4}$ K. Bertens, Etika (Jakarta: Gramedia Pustaka Utama, 2007), h. 4.

${ }^{5}$ Moral yang merupakan istilah dari bahasa Latin, yaitu "Mos" dan dalam bentuk jamaknya "Mores", yang berarti juga adat kebiasaan atau cara hidup seseorang dengan melakukan perbuatan yang baik (kesusilaan), dan menghindari hal-hal tindakan yang buruk. Etika dan moral lebih kurang sama pengertiannya, tetapi dalam kegiatan seharihari terdapat perbedaan, yaitu moral atau moralitas untuk penilaian perbuatan yang dilakukan, sedangkan etika adalah untuk pengkajian sistem nilai-nilai yang berlaku. Istilah lain yang identik dengan etika, yaitu: "Susila (Sanskerta), lebih menunjukkan kepada dasar-dasar, prinsip, aturan hidup (sila) yang lebih baik. Lihat Maidiantus, Pendidikan, h. 237. Sya'roni dalam tulisannya, etimologi kata "etika" sama dengan etimologi kata "moral", karena keduanya berasal dari kata yang berarti adat kebiasaan. Hanya bahasa asalnya berbeda; yang pertama berasal dari bahasa Yunani, sedang yang kedua dari bahasa Latin. Moral adalah ajaran-ajaran wejangan-wejangan khutbah-khutbah patokan-patokan tentang bagaimana manusia harus hidup dan bertindak agar ia menjadi manusia yang baik. Sumber langsung ajaran moral dapat berupa ajaran agama, nasihat para bijak, orang tua, guru dan sebagainya. Pendek kata sumber ajaran moral meliputi agama, tradisi, adatistiadat dan ideologi-ideologi tertentu. Lihat Mokh Sya'roni, "Etika Keilmuan," dalam Teologia, Vol 25,Juni 2014, h.316. pada satu tempat belum tentu diterima ditempat yang lain. Tergantung alat apa yang digunakan bahwa suatu sikap dan prilaku itu salah atau sebaliknya. Dengan demikian, etika dimanapun tetap menjadi barometer. Tetapi rujukan yang digunakan mempunyai sumber yang berbeda. Kalau dalam Islam tentu yang menjadi acuan Al-Quran dan Sunnah. Walaupun dalam perkara prilaku umum ada yang disepakati.

\section{b. Belajar}

Kata "belajar" secara leksikal dalam bahasa Indonesia memiliki beberapa pengertian, yaitu: 1. usaha untuk memperoleh kepandaian/ilmu, 2. berlatih, dan 3. perubahan tingkah laku atau tanggapan yang disebabkan oleh pengalaman. ${ }^{6}$ Apabila mengacu dari definisi di atas ada beberapa hal yang menjadi kajian pemakalah, bahwa kata "memperoleh ilmu" adalah mewakili tentang kemampuan kognitif. Seseorang yang awalnya tidak mengetahui sesuatu, lalu belajar satu bidang ilmu atau beberapa keilmuan dan mendapatkannya. Pada Tahap ini belajar lebih menitik

${ }^{6}$ Pendidikan Nasional, Kamus, h. 17. 
tekankan kepada pengisian ranah

kognisi. Sedangkan kata " berlatih"

lebih melihat dari aspek

psikomotorik, yakni berupa

keterampilan. Ketika Rasul

mengajarkan dan mengajak para

orang tua untuk melatih anaknya

berkuda dan memanah. Ungkapan

Rasul tersebut apabila ditinjau dalam ranah belajar, lebih dekat kepada aspek psikomotorik. Menitiktekankan pada ketrampilan atau olah raga. Sedangkan kata "perubahan tingkah laku" lebih fokus pada konteks afektif, perasaan. Seorang yang belajar dituntut mengalami suatu perubahan sikap kearah yang lebih matang dan dapat mempertanggung-jawabkan segala hal yang dilakukan. Ini menandakan bahwa makna belajar bicara dari tiga unsur(kognitif, psikomotorik, dan afektif). Sepertinya definisi yang dijabarkan Pendidikan Nasional, sarat dengan pesan teologis. Seorang ilmuan, cendikiawan yang mumpuni dengan ilmunya masing-masing dipundaknya ada beban dan tanggung jawab untuk mengintegrasikan antara imu dan amal.
Hal yang sangat berbeda dengan Piaget, dia mengartikan belajar dalam dua makna, pertama dalam makna sempit dan kedua dalam arti luas. Belajar dalam arti sempit adalah belajar yang hanya menekankan perolehan informasi baru dan pertambahan. Sedangkan belajar dengan makna luas, adalah menemukan struktur pemikiran yang lebih umum yang dapat digunakan pada bermacam-macam situasi. ${ }^{7}$ Ulasan yang disampaikan Piaget lebih menekankan kepada ranah kekuatan kognitif oriented. $^{8} \quad$ Makanya pemakalah tidak sependapat dengan

7 Piaget memberikan contoh tentang belajar dalam arti sempit, seorang anak belajar nama-nama ibu kota suatu Negara atau menghafalkan nama-nama angka. Belajar ini disebut dengan belajar figuratif. Sedangkan contoh belajar dalam arti luas, dalam menghafal ibu kota Negara-negara, seorang anak juga mengerti hubungan antara kota dengan Negara. Lihat, Paul Suparno, Teori perkembangan Jean Piaget (Jakarta: Kanisius, tt), h. 140-141.

${ }^{8}$ Dapat dimaklumi bahwa Piaget yang lahir di Neuchatel, Swiss. mengalami krisis iman pada usia muda. Walaupun sudah didorong ibunya untuk mengikui kajian keagamaan namun Piaget memberikan penilaian bahwa iman tidak memberikan kesan dan cendrung ajarannya bersifat kekanak-kanakan. Maka sangat wajar definisi belajar di sini tidak menyentuh aspek yang berhubungan dengan nilai spiritual. Dia seorang psikolog kelahiran 9 Agustus 1896 . Lihat Ladidlaus Naisaban, Para Psikolog Terkemukan di Dunia (Jakarta: Grasindo, $\mathrm{tt}$ ), h. 322 . 
makna dan contoh yang disampaikan

Piaget. Karena kebutuhan dari manusia tidak hanya mengacu kepada aspek di atas. Ada beberapa aspek lain yang juga tidak kalah penting dan keutamaannya. ${ }^{9}$ Sebagaimana yang disampaikan Sumadi Suryabrata belajar adalah aktivitas yang dihasikan, perubahan pada diri individu yang belajar (dalam arti behavioral) baik aktual maupun potensial. Perubahan itu pada pokoknya adalah diperolehnya kemampuan baru yang berlaku dalam waktu yang relatif lebih lama; perubahan itu terjadi karena usaha. ${ }^{10}$

\section{c. Mengajar}

Kata mengajar mempunyai beberapa makna, antara lain:

1. Memberi pelajaran

2. Melatih
3. Memarahi (memukul, menghukum dan sebagainya) supaya jera. ${ }^{11}$

Orang (pengajar) melakukan hal di atas disebut juga seperti guru dan pelatih. ${ }^{12}$ Apabila landasan ini jadi pegangan, pemakalah memberikan sebuah argumentasi bahwa seorang guru boleh memukul muridnya sebagai bagian dari profesi mengajar. Bertujuan menimbulkan efek jera kepada si murid. Dengan demikan yang dilihat bagaimana tujuan tercapai sebagai mana yang diharapkan. Dalam bahasa Inggris mengajar diartikan dengan kata teach, yang berasal dari bahasa Inggris kuno yaitu taecan yang berarti to teach yaitu mengajar. Aktivitas mengajar menyangkut peranan seorang guru dalam konteks mengupayakan terciptanya jalinan komunikasi harmonis antara pengajar itu sendiri dengan si pelajar. $^{13}$ Hubungan antara si pelajar dan si pengajar merupakan yang dimiliki oleh manusia. Belajar juga megubah tingkah laku. Belajar adalah mengubah tindakan, cara kerja, gaya hidup dan praktek hidup kita. Kesimpulannya adalah belajar adalah mengubah keseanteroan diri, Lihat, Andra Ismail, Selamat Menabur (Jakarta: Gunung Mulia, 2008), h. 121.

${ }^{10}$ Arif Hidayat Afendi , Al-Islam Studi Alquran; Kajian Tafsir Tarbawi (Yogyakarta: Deepublish, 2016 ), h. 35-36. 17. ${ }^{12}$ Ibid.

13 Rofa'ah, Pentingnya Kompetensi guru dalam kegiatan pembelajaran dalam perspektif Islam (Yogyakarta: Deepublish, 2016), h. 62.
11 Departemen Nasional, Kamus, h. 
bagian yang tidak bisa dipisahkan. Tanpa adanya salah satu, maka aktivitas tersebut tidak bisa disebut dalam suasana belajar dan mengajar. Ditinjau dengan menggunakan pendidikan Islam, kedua sisi ini saling mendukung, karena prinsip menuntut ilmu dalam Islam, lahirnya manusia yang yang dinamis dengan mengoptimalkan segala materi dan kesempatan yang diberikan Allah. Jusuf Amir Feisal mengatakan bahwa Sebenarnya esensi pendidikan Islam adalah memuliakan manusia dan budaya yang diridhoi oleh Allah. ${ }^{14}$ budaya di sini adalalah kebiasaan baru yang muncul dikarenakan sebelumnya ada proses belajar.

\section{d. Etika Belajar}

Seorang yang mau belajar terlebih dahulu harus membersihkan jiwa dari pengertian pendidikan Islam diwakili oleh Istilah taklim dan tarbiyah yang berasal dari kata dasar allama dan rabba sebagaimana yang digunakan dalam Alquran, sekalipun konotasi kata tarbiyah lebih luas karena mengandung arti memelihara, memberikan dan mendidik, serta sekaligus mengandung makna mengajar ( allama), lihat, Jusuf Amir Feisal, Reorientasi Pendidikan Islam (Jakrta: Gema Insani, 1995), h. 94-95. segala bentuk akhlak yang tercela. Didasari oleh sabda Rasul saw: ${ }^{15}$

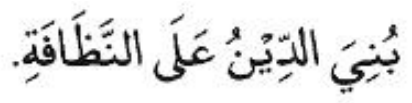

Maksud di sini bukan kebersihan pakaian semata, akan tetapi juga kebersihan hati. ${ }^{16}$ Dalam hal ini, orang yang dalam suasana belajar, yang disiapkan bukan hanya pikiran, tetapi seluruh aspek yang turut membantu dalam proses internalisasi ilmu ke dalam diri murid. Seorang murid harus menghilangkan sifat terburu-buru dalam mendapatkan ilmu. Konsisten dan sabar merupakan bagian yang tidak bisa dilepaskan dalam setiap pelajar. Arif memasukkan dua ayat sebagai bagian nilai dan sikap yang selayaknya dimiliki oleh pelajar ${ }^{17}$, firman Allah: ${ }^{18}$

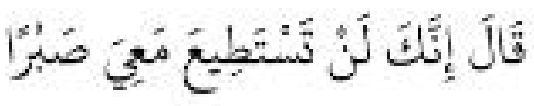

\footnotetext{
15 "Agama itu didirikan diatas pondasi nilai- nilai kebersihan" lihat, Mahajjutaul Baidha, $h 281$.

16 Al-Ghazali, Ihya Ulumuddin , terj Abdul Rosyad (Jakarta: Akbar Media, 2009), h. 11 .

17 Afendi, Al-Islam, h. 34.

18 Sesungguhnya kamu sekali-kali tidak sanggup bersabar bersamaku
} 
Pelajar juga harus mempunyai sikap tidak terburu-buru dan tidak memaksakan guru untuk menjelaskan sesuatu yang belum saatnya. Allah berfirman: ${ }^{19}$

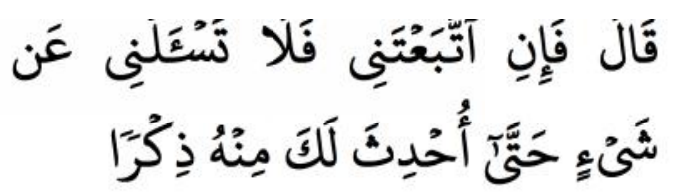

Seorang pelajar haruslah menampilkan sosok yang bersahaja dan sikap memuliakan gurunya. Maka sudah menjadi hal yang lumrah etikaperlu dijaga oleh si pelajar dan juga menjaga sikap dan prilaku terpuji dihadapan gurunya. Sebagaimana sikap sahabat -sahabat Rasul saw, takkala berada di majelisnya. Abu> Sa'id Al-Khudri> berkata: ${ }^{20}$

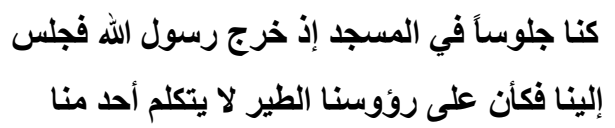

Al-Ghazali menjelaskan ada beberapa hal yang mesti dijaga bagi menuntut ilmu:

\footnotetext{
19 “Jika Kamu Mengikutiku, maka jangan kamu menanyakan sesuatu kepadaku sampai aku sendiri menjelaskan kepadamu” Lihat Q.S Al-kahfi [18]: 70.

20 "Saat kami sedang duduk-duduk di masjid, maka keluarlah Rasulullah shallallahu 'alaihi wa sallam kemudian duduk di hadapan kami. Maka seakan-akan di atas kepala kami terdapat burung. Tak satu pun dari kami yang berbicara" (HR. Bukhari).
}

1. Menyucikan hati dari prilaku yang buruk dan sifat-sifat yang tercela $^{21}$. Rasul saw selalu berupaya sekuat tenaga untuk menjauhkan diri dari segala perbuatan dosa. $^{22}$

2. Mengurangi segala keterkaitan dengan kesibukan-kesibukan duniawi dan menjauh dari keluarga dan kota tempat tinggal.

3. Tidak bersikap angkuh terhadap ilmu dan tidak pula menonjolkan kekuasaan terhadap guru yang mengajari, tetapi menyerahkan bulat-bulat kendali dirinya dan mematuhi segala nasehatnya. ${ }^{23}$ Prilaku angkuh akan mematikan hati dan dibenci oleh Rasul. Karena dia sendiri menjauhi sifat itu. $^{24}$

21 AlGhazali, Ilmu dalam Perspektif Tasawwuf Al-Ghazali, terj Muhammad AlBaqir (Bandung: Karisma, 1996), h.165.

22 "Tidaklah disuruh memilih sesuatu di antara dua pekerjaan, melainkan Rasul mengambil yang paling mudah. Selama yang paling mudah itu tiada membawa kepada dosa" (HR. Bukhari) lihat juga Tengku Muhammada Hasbi Ash Shiddieqy, Mutiara hadits (Semarang: Pustaka Rizki Putra, 1952), h. 543.

${ }^{23}$ Ibid.

24 "Aku adalah penghulu semua anak Adam pada hari kiamat, dan aku tidak ada rasa bangga dengan diri sendiri" lihat Muhammad Al-Utsaimin, Syarah Riyadhus Shalihin Imam Nawawi (Jakarta: Darul Falah, 2007), h. 353. 
4. Bagi seorang pemula dalam upayanya menuntut ilmu, ialah tidak memalingkan perhatiannya sendiri untuk mendengar pendapat manusia yang bersimpang siur; baik ilmu yang sedang dipelajarinya itu termasuk ilmu-ilmu dunia maupun ilmu akhirat, sebab akan menimbulkan keraguan dan kebingungan dalam pikirannya sendiri, melemahkann semangatnya dan membuatnya putus asa untuk meraih pengetahuan.

5. Bagi seorang penuntut ilmu adalah menunjukkan perhatiannya yang sungguhsungguh kepada tiap- tiap disiplin ilmu yang terpuji.

6. Hendaklah ia tidak melibatkan diri dalam berbagai macam ilmu pengetahuan secara bersamaan.

7. Hendaknya ia tidak melibatkan diri dalam suatu bagian ilmu sebelum menguasai bagian yang sebelumnya. Sebab semua ilmu berurutan secara teratur.

8. Hendaknya ia berusaha mengetahui apa kiranya yang menjadikan sesuatu menjadi semulia- mulia ilmu. Ini dapat diketahui dengan memperhatikan dua hal: Pertama, kemuliaan buah dari ilmu tersebut, dan kedua, kemantapan dan kekuatan dalil yang menopangnya.

9. Hendaknya seorang penuntut ilmu menjadikan tujuannya segera, demi menghiasi batinnya dengan segala aspek kebajikan. Sedangkan tujuan selanjutnya demi mendekatkan diri kepada Allah.

10. Seorang penuntut ilmu hendaknya megetahui hubungan suatu ilmu dengan tujuannya. Agar dengan demikian ia dapat mendahulukan yang dekat sebelum yang jauh, dan sesuatu yang sangat penting adalah memenuhi kepentingan sendiri. Tidak ada yang lebih penting untuk anda selain keselamatan dan kesejahteraan di dunia dan di akhirat. $^{25}$

Mencermati ulasan alGaza>li> bagaimana selayaknya seorang penuntut ilmu bersikap. Lebih menitik-tekankan kepada batin

${ }^{25}$ Al-Ghazali, Ilmu, h.165-181. 
si pelajar dan fokus kepada kehidupan mata batin. Hal ini dianggap wajar, karena perspektif yang digunakan lebih kepada demensi tasawwuf. Memiliki rasa hormat dan bersikap santun terhadap guru adalah prilaku yang harus dimiliki dalam menuntut ilmu. Guru adalah orang yang memberikan ilmu, yang dengan ilmu itu orang menjadi mulia baik di dunia maupun di akhirat. Sebagaimana sabda Rasulullah : ${ }^{26}$

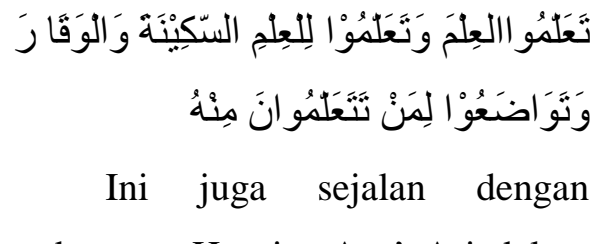

pandangan Hasyim Asy’ Ari dalam kitab Adab-al-'A>lim wal Mutaalim.

Dia mengatakan bahwa murid harus:

Pertama, bagi murid hendaknya berniat suci untuk menuntut ilmu, jangan berniat untuk hal-hal duniawi dan jangan melecehkan atau menyepelekannya.

Kedua, bagi guru dalam mengerjakan ilmu hendaknya meluruskan niatnya terlebih dahulu, tidak mengharapkan materi semata-mata. Di samping itu, yang diajarkan hendaknya sesuai

26 "Belajarlah kalian ilmu untuk
ketentraman dan ketenangan serta rendah
hatilah pada orang yang kamu belajar
darinya" (HR.At-Tabrani).

dengan tindakan-tindakan yang diperbuat. Dalam hal ini yang dititik beratkan adalah pada pengertian bahwa belajar merupakan ibadah untuk mencari ridha Allah yang mengantarkan seseorang memperoleh kebahagiaan dunia dan akhirat. ${ }^{27}$

Apabila melihat dari beberapa tulisan dari masing- masing ulama di atas menunjukakan bahwa etika utama yang harus ditonjolkan pada setiap pelajar adalah kebersihat jiwa, ini juga dipertegas oleh Imam Nawawi, bahwa:

1. Hendaklah peserta didik menjauhi hal-hal yang menyibukkan kecuali sebabsebab yang harus dilakukannya karena merupakan kebutuhan

2. Membersihkan hati dari kotorankotoran dosa supaya hati menjadi baik untuk menerima Al-Qur"an , menghafalkannya dan menghafalkannya.

3. Hendaklah peserta didik bersikap tawadhu" terhadap pendidiknya meskipun pendidiknya lebih

27 Edi Hariyanto, "Etika Guru dalam Proses Belajar Mengajar Agama Islam Menurut KH. Hasyim Asy'ari Dalam Kitab Adabul Alim wal Muta'allim" (Thesis, I AIN Wali Songo, 2011), h. 28. 
muda darinya, kurang tersohor, lebih rendah nasabnya dan buruk perilakunya, dan hendaklah peserta didik bersikap tawadhu'e terhadap ilmu, karena dengan sikap tersebut peserta didik akan mendapatkan ilmu."

4. Hendaklah peserta didik patuh kepada pendidiknya dan membicarakan segala urusannya. Dia terima perkataannya seperti orang sakit yang berakal menerima nasihat dokter yang mempunyai kepandaian, maka yang demikian itu lebih utama. ${ }^{28}$ Etika pelajar bukan hanya antara dia dengan gurunya, tapi juga antara dia dengan Tuhannya dan antara dia dengan ilmunya.

\section{e. Etika Mengajar}

Guru adalah contoh nyata bagi murid. Sudah menjadi hal yang wajar, teladan merupakan metode yang paling mujarab dalam menanamkan nilai-nilai kepada murid. Inilah salah satu kekuatan Rasul saw., terletak pada pribadinya.

${ }^{28}$ Imam Nawawi, At-Tibyan Fi Adabi Hamalatil Qur"an, (Beirut: Darul Minhaj, 2015), h. 63.
Hasyim Asy`Ari menyampaikan ada beberapa yang mesti dijaga oleh para pengajar, di antaranya:

a. Selalu mendekatkan dirikepada Allah dalam berbagai kondisi dan situasi.

b. Senantiasa takut kepada murka siksa Allah dalam setiap gerak, diam, perkataan dan perbuatan.

c. Senantiasa sakinah atau tenang. ${ }^{29}$ Sikap hidup yang baik dapat ditampilkan dengan wajah yang menarik. Inilah yang dingatkan Rasul untuk menarik simpati orang kepadanya. ${ }^{30}$

d. Senantiasa berhati-hati dalam perkataan dan perbuatan.

e. Selalu rendah hati atau tidak menyombongkan diri.

f. Senantiasa kepada Allah

g. Senantiasa berpedoman kepada hukum Allah dalam setiap hal.

h. Tidak menjadikan ilmu yang dimiliki sebagai sarana mencari keuntungan duniawi, seperti harta benda kedudukan (jabatan).

\footnotetext{
${ }^{29}$ Hariyanto, Etika, h. 67.

30 "Kamu Tidak bisa memperoleh semua orang dengan hartamu tetapi dengan wajah yang menarik ( simpati) dan dengan akhlak yang baik",lihat, Chaniago, Syarah,
} h. 139. 
i. Tidak merasa rendah di hadapan para pemuja dunia orang yang punya kedudukan dan harta benda, tidak pula mengagungkan mereka dengan sering-sering berkunjung dan berdiri menyambut kedatangan mereka tanpa kemaslahatan apapun di dalamnya.

j. Zuhud, tidak terlampau mencintai kesenangan duniawi dan rela hidup sederhana. Jika ia membutuhkan dunia sekedar untuk mencukupi kebutuhan diri dan keluarga.

k. menjauhi pekerjaan / profesi yang dianggap rendah/ hina) menurut pandangan adat maupun syariat.

1. Menghindari tempat-tempat yang dapat mendatangkan fitnah, serta meninggalkan hal-hal yang menurut pandangan umum dianggap tidak patut dilakukan meskipun tidak ada larangan atasnya dalam syariat Islam.

m. Menghidupkan syiar dan ajaranajaran Islam) seperti mendirikan shalat berjama'ah di masjid, menebarkan salam kepada orang lain, menganjurkan kebaikan dan mencegah kemungkaran dengan penuh kesabaran (dalam menghadapi resiko yang menghadang).

n. Menegakkan sunnah Rasul saw serta memperjuangkan kemaslahatan umat Islam dengan cara-cara yang populis (memasyarakat) dan tidak asing bagi mereka.

o. Menjaga hal-hal yang sangat dianjurkan oleh syari'at, baik berupa perkataan maupun perbuatan), seperti memperbanyak membaca Alquran, berdzikir dengan hati maupun lisan.

p. Mempergauli manusia dengan akhlak-akhlak terpuji seperti bersikap ramah, menebarkan salam, menahan (emosional), tidak suka menyakiti, tidak berat hati dalam memberi penghargaan (kepada yang berhak) serta tidak terlalu menuntut untuk dihargai. ${ }^{31}$ Sebagaimana mana nasehat Rasul saw. $^{32}$

\footnotetext{
${ }^{31}$ Hariyanto, Etika, h. 69-70.

32 "Seorang mukmin yang paling utama Islamnya, ialah terselamatkannya orang -orang muslim lainnya dari lisan dan tangannya;dan orang mikmin yang
} 
q. menyucikan jiwa dan raga dari akhlak-akhlak tercela), dan menghiasi keduanya dengan akhlak-akhlak mulia.

r. Selalu berusaha mempertajam ilmu pengetahuan dan amal), yakni melalui kesungguhan hati dan ijtihad, muthala'ah (mendaras), muzakarah (merenung), taliq (membuat catatan-catatan), menghafal dan melakukan pembahasan (diskusi).

s. Tidak merasa segan mengambil faedah (ilmu pengetahuan) dari orang lain atas apapun yang belum dimengerti), tanpa memandang perbedaan status atau kedudukan, nasab/ garis keturunan, dan usia. ${ }^{33}$

t. Meluangkan sebagian waktu untuk kegiatan menulis, mengarang atau menyusun kitab).

paling utama imannya ialah yang paling baik Akhlaknya"(HR. Thabrani), lihat Muhammad Alfis Chaniago, Indeks Hadist Dan Syarah (Bekasi: Alfonso Pratama, 2012), h. 127.

${ }^{33}$ Hariyanto, Etika, h. 72
Abdul Mujib menambahkan bahwa seorang pengajar juga harus: ${ }^{34}$

a. Menerima segala problem peserta didik dengan hati dan sikap yang terbuka dan tabah.

b. Bersikap penyantun dan penyayang $^{35}$

c. Menjaga kewibawaan dan kehormatannya dalam bertindak.

d. Menghindari dan menghilangkan sikap angkuh terhadap sesama. ${ }^{36}$

e. Bersifat rendah hati ketika menyatu dengan sekelompok masyarakat. $^{37}$

f. Menghilangkan aktivitas yang tidak berguna dan sia-sia.

g. Bersifat lemah lembut dalam menghadapi peserta didik yang tingkat IQ-nya rendah, serta membinanya sampai pada taraf maksimal.

h. Meninggalkan sifat marah dalam menghadapi problem peserta didiknya.

i. Memperbaiki sikap peserta didiknya, dan bersikap lemah

${ }^{34}$ Abdul Mujib dan Jusuf Mudzakkir, Ilmu Pendidikan Islam ( Jakarta: Kencana, 2008), h. 99.

${ }^{35}$ QS. Ali Imran [3]: 159.

${ }^{36}$ QS. Al- Najm[53]: 32.

${ }^{37}$ QS. AlHijr[15]: 17. 
lembut terhadap peserta didik

yang kurang lancar bicaranya.

Menurut Ibnu Jama'ah, seorang guru juga harus mempunyai etika, sopan santun, memudahkan dan menyenangkan dan menyelamatkan, memiliki sifat keagamaan yang baik, memiliki sifat atau akhlak yang mulia, senantiasa berzikir dan membaca Al-Quran. ${ }^{38}$ Pelajar dan pengajar menjadi orang yang diangkat derajatnya oleh Allah. Al-Quran mengangkat mereka karena keilmuan yang dilmiliki. Fiman Allah: ${ }^{39}$

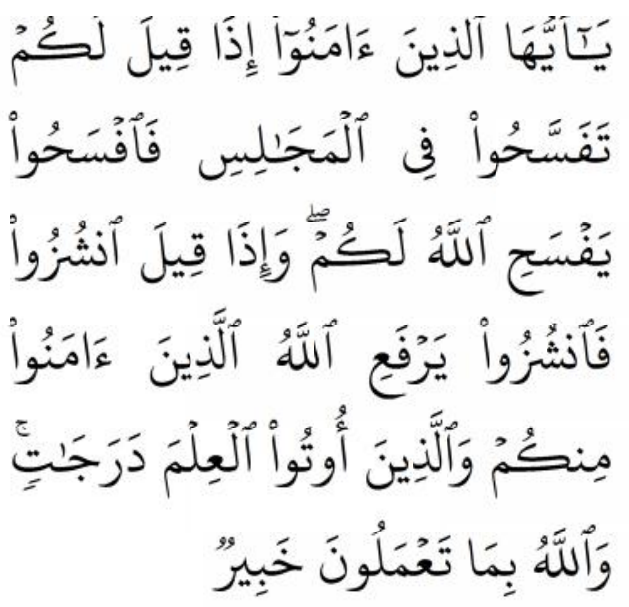

\footnotetext{
${ }^{38}$ Mudzakkir, Ilmu, h. 98.

39 "Wahai orang -orang yang beriman apabila dikatakan kepadamu berlapang-lapanglah dalam majelis”, maka lapangkanlah niscaya Allah akan memberi kelapangan untukmu dan apabila dikatakan kepadamu "berdirilah kamu" maka beridrilah Allah mengangkat derajat orangorang yang beriman diantaramu dan orangorang yang berilmu beberapa derajat dan Allah maha mengetahui apa yang kamu kerjakan”Lihat, QS. Al Mujadalah, [58]:11
}

Hamka menjelaskan ayat ini bahwa ini mengajarkan kepada pengikut majelis Rasul saw untuk selalu tertib dan rapi dalam suasana mendengar nasehat -nasehat Rasul, Hamka juga menguraikan bahwa iman dan ilmu haruslah berjalan seiring. Iman yang tidak disertai ilmu membawa dirinya terperosok mengerjakan pekerjaan yang disangka menyembah, padahal mendurhakai Allah. Sebaliknya orang yang berilmu saja tidak disertai atau yang tidak membawanya kepada iman, makanya ilmu itu dapat membahayakan dirinya sendiri ataupun bagi sesama manusia. ${ }^{40}$ Hubungan yang baik antara murid dan guru menjadi salah satu pilar yang harus dirajut agar antara satu dengan yang saling memuliakan. Keduanya saling menampilkan etika. Sebagai seorang murid berupaya sekuat mungkin menghadirkan prilaku yang bertanggung jawab. Hal yang sama juga diwajibkan bagi seorang pengajar.

${ }^{40}$ Hamka, Tafsir Al-Azhar (Singapura: Pustaka Nasional, 2003), h. 7229. 


\section{Penutup}

Murid dan guru, belajar dan mengajar kedua objek ini masingmasing mempunyai etika yang wajib dipatuhi. Karena yang dikehendaki dalam Islam, bukan hanya ahli dalam ilmu tertentu. Tetapi juga mampu memiliki keutamaan diri. Anggun dalam moral unggul dalam Intelektual. Kedua hal ini ibarat sisi koin yang tidak terpisahkan. Seseorang yang dalam kondisi belajar, menyerap ilmu dari guru yang megajarkan. Selayaknya menampilkan sikap hormat dan memuliakan gurunya. Bersikap lembut dan kasih sayang murid kepada guru menjadi hal yang terelakkan. Hal inilah yang mulai dan sedang tergerus, di tengah-tengah kehidupan era teknologi dan demokrasi. Seolah-olah guru hanya sebagai alat transfer knowledge. Sehingga murid melepaskan diri dari nilai sakral yang wajib dipenuhinya. Tidak sombong, menjaga sikap dan ucapan, istiqomah dalam belajar, disiplin, menghormati antar sesama adalah contoh sikap yang di jungjung tinggi.
Sebagaimana halnya dengan sikap seorang pelajar, prilaku yang sama juga utama ditunjukkan oleh pengajar. Mereka bukan hanya petugas mencurahkan ilmu. Tapi juga seorang teladan. Islam sangat membutuhkan para intelektual. Tapi agama ini perlu pemeluknya menampilkan sikap sebagaimana Rasul saw. Dengan nilai kasih dan sayang yang ditunjukkan guru kepada murid, merupakan salah satu domain utama agar muncul rasa hormat kepada pelajar. Tidak membedabedakan antara satu dengan yang lain. Memiliki sikap rendah hati, pribadi yang menyejukkan adalah sifat- sifat yang tidak bisa diabaikan demi melahirkan generasi rabbani. Pelajar dan pengajar sama-sama mempunyai tugas dan ranahnya masing-masing untuk menjaga etika selama proses kegiatan belajar tersebut berlangsung.

\section{Daftar Pustaka}

Al-Ghazali. Ihya Ulumuddin. Terj Abdul Rosyad. Jakarta: Akbar Media, 2009.

Ilmu dalam Perspektif Tasawwuf Al-Ghazali, terj 
Muhammad

Bandung: Karisma, 1996.

Al-Utsaimin, Muhammad. Syarah Riyadhus Shalihin Imam Nawawi. Jakarta: Darul Falah, 2007.

Alfis Chaniago, Muhammad. Indeks Hadist Dan Syarah. Bekasi: Alfonso Pratama, 2012.

Amir Feisal, Jusuf. Reorientasi pendidikan Islam. Jakarta: Gema Insani, 1995.

Bertens, K. Etika. Jakarta: Gramedia Pustaka Utama, 2007.

Departemen Agama republik Indoneisa. Alquran dan Terjemahnya. Jakarta: Bandung: Gema Risalah, 1992.

Hasbi Ash Shiddieqy, Tengku Muhammad. Mutiara hadits. Semarang: Pustaka Rizki Putra, 1952.

Hariyanto, Edi Etika Guru dalam Proses Belajar Mengajar Agama Islam Menurut KH. Hasyim Asy'ari Dalam Kitab Adabul Alim wal Muta'allim. (thesis, I AIN Wali Songo, 2011.

Hidayat Afendi, Arif. Al-Islam Studi Alquran; Kajian Tafsir Tarbawi. Yogyakarta: Deepublish, 2016.

Hamka, Tafsir Al-Azhar. Singapura: Pustaka Nasional, 2003.
Ismail, Andra. Selamat Menabur. Jakarta: Gunung Mulia, 2008.

Jusuf Mudzakkir, Abdul Mujib. Ilmu Pendidikan Islam. Jakarta: Kencana, 2008.

Maidiantus. "Pendidikan Kajian Etis tentang Krisis Moral Berdampak Pada pendidikan," dalam Jaffray, vol.2. Oktober 2014.

Nawawi,Imam. At-Tibyan Fi Adabi Hamalatil Qur"an. Beirut: Darul Minhaj, 2015.

Naisaban, Ladidlaus. Para Psikolog Terkemukan di Dunia. Jakarta: Grasindo, tt.

Tim Penyusun Departemen Pendidikan Nasional. Kamus Besar Bahasa Indonesia. Jakarta: Gramedia Pustaka,2007.

Paul Suparno, Teori perkembangan Jean Piaget. Jakarta: Kanisius, tt.

\section{Rofa'ah. Pentingnya Kompetensi guru dalam kegiatan pembelajaran dalam Perspektif Islam. Yogyakarta: Deepublish, 2016.}

Surajiyo. Ilmu Filsafat Suatu Pengantar. Jakarta: Bumi Aksara, 2005.

Sya'roni, Mokh "Etika Keilmuan," dalam Teologia, Vol 25,Juni 2014. 